\title{
Lessons on Government from One Non-State Entity to Another:
}

\section{How the Irish Republican Movement Informs Hezbollah's \\ Attempt at the Clausewitzian Political Arm}
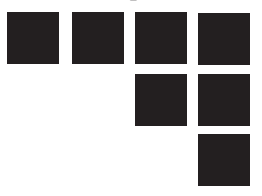

Paul Baumgardner

Ph.D Candidate, Political Science and Government

University of Michigan

The great nineteenth-century military theorist Carl von Clausewitz changed the art of war forever with his masterwork, "On War." This text illuminated one of Clausewitz's greatest contributions to military thought: the Trinity of war. Clausewitz argued that a successful military campaign requires the balanced cooperation of three important levels of society: the political wing (the government), the military wing (the army), and the popular wing (the citizenry). In modern warfare, Clausewitz's Trinity still remains an important lesson, especially for non-state actors. By examining the Irish Republican Army and Hezbollah, we can better understand how non-state actors balance the three branches of the Trinity and achieve their sociopolitical objectives.

As the threat of Napoleonic power aggrandizement threatened Europe in the late nineteenth century, many nations dedicated their best minds to the task of repelling Napoleon's French forces. In 1812, Carl von Clausewitz published a piece on warfare that would affect the military landscape generations after Napoleon's death. In On War, Clausewitz argued that Europe needed thinking officers, who were capable of philosophically grappling with the very nature of warfare. Clausewitz's logic was simple: in order to ascertain Napoleon's military weaknesses, competing European leaders would have to understand the intricacies of the art of war. Clausewitz's most important contribution to the understanding of war was his theory of the sociopolitical "Trinity." A successful political agenda, and war strategy, depended upon the relationship of three entities: "The first of these three aspects mainly concerns the people; the second the commander and his army; the third the government."1 Although the conventions of war, and the global conceptions of sovereignty, have shifted since the early nineteenth century, Clausewitz's fundamental assertions about maintaining a balanced Trinity seem more applicable than ever to national actors. However, the modern rise of non-state actors has provided a surprising twist to the history of conflict. Unlike state actors, who rest on institutionalized government and military structures to maintain equilibrium, non-state entities are less institutionalized and more likely to be held together by a central ideology or moral ideals. In this essay, I shall compare the Irish Republican Army (IRA), which has successfully transitioned into a legitimate Clausewitzian government

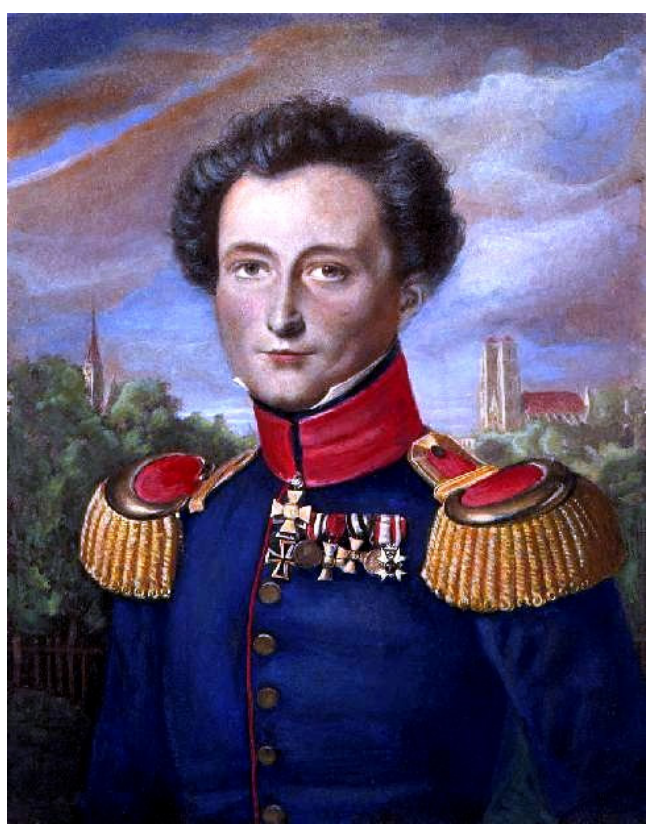

Carl von Clausewitz

arm, with the Shiite group, Hezbollah. This juxtaposition will prove to contemporary non-state movements that only through a 
transmogrification of military objectives into political operations will a balanced Clausewitz's Trinity be achieved and sociopolitical gains be made possible.

An understanding of the government branch of the Clausewitzian Trinity will inform the comparative relationship between the IRA and Hezbollah. Therefore, a proper assessment of these modern guerrilla actors first requires a thorough investigation into the broader, philosophical fabric of Clausewitz's On War. Clausewitz does not posit an idealistic or noble conception of war, but a conception depicting the ugliness and unpredictability of conflict. It is this unpredictability that leads Clausewitz to argue that the three branches of the Trinity are "deep-rooted in their subject and yet variable in their relationship to one another." ${ }^{2}$ Although this essay shall focus on the political arm of Clausewitz's Trinity theory, it is important to remember that a policy which ignores any one of the three branches, or seeks to fix an arbitrary relationship between them, would be useless. A static model of the balanced Trinity cannot be offered. A belligerent must be able to oversee the empowerment of one branch, and the circumscription of another, if circumstances change. It is for this reason that the Trinity balance conceived by state entities must be different than the balance conceived by non-state entities.

The ways in which war's friction affects the public branch of the Trinity differs depending on whether the actor retains the institutionalized support of a government. Additionally, the structural limitations placed upon statesponsored armies are significantly different than the military limitations found in a guerrilla movement. It is for this reason that I researched outside the purview of Middle East nations: to find an equally volatile non-state entity, a comparable non-state movement that had shown a recent acceptance of Trinity verities.

\section{The Origin of Hezbollah}

Hezbollah, or "The Party of God", is a controversial terrorist/political/social worksorganization that sprang into prominence after the Israeli invasion of Lebanon in 1982. For historians, Israel's invasion and lasting occupation within Lebanon became the most significant factor in the radicalization of the Lebanese Shiites under Hezbollah. Hezbollah leaders rationalize the use of military extremism by appealing to the fact that Israel created the context for Hezbollah's birth and its continued growth. The presence of a foreign occupying force-which imposes uncomfortable legal, economic, and political changes on the native population-has been the catalyst for many historic guerrilla movements. Hezbollah's role in Lebanese politics can be traced back to 1984, but its ideological foundation began even earlier in the 1980s. However, it is important to note that Lebanese contempt for the Israeli state probably would have fizzled out as a minor rebellion, and never would have grown into a united populist ideology, unless external political forces had aided in the early resistance movement.

Over the past three decades, Syria and Iran have significantly influenced the ideology and political growth of Hezbollah. Following a successful Islamic revolution over the secular shah, opportunistic Iranian mullahs turned their sights to the rest of the Middle East. Sandra Mackey writes, "For Iran's revolutionary leaders correctly saw in Lebanon a fertile opportunity to spread the Islamic revolution beyond the borders of Iran. With a large Shiite population historically and emotionally tied to Iran, Lebanon was chosen as the country in which Iran would demonstrate the power of its revolution." ${ }^{2}$ By financing Hezbollah, and providing arms and training to its guerrilla fighters, the Iranian government has been granted a powerful hand in shaping Hezbollah's future. To this day, Iran's blandishments have allowed the nation to hold substantial sway over the governing hierarchy of Hezbollah:

Iran has sponsored the creation of a Consultative Council for Lebanon. The council supervises the work of Hezbollah within Lebanon and serves as the nodal connection between Iran 
and Lebanon. It consists of twelve men, most of whom are clerics, the remainder being military officials. The council subsumes seven committees named as follows: intellectual, financial, political, information, military, social, and legal. The entire operation appears to be wellfinanced from Iran; not only are operating expenses provided, but there is also an extensive system for the payment of pensions to the families of individuals martyred in the cause of Hezbollah. ${ }^{4}$

Whereas Iranian influence tends to use Southern Lebanon, and Hezbollah, as a second breeding ground for revolutionary Islamic political thought, the nation of Syria has been more strategic with its marionette strings. After

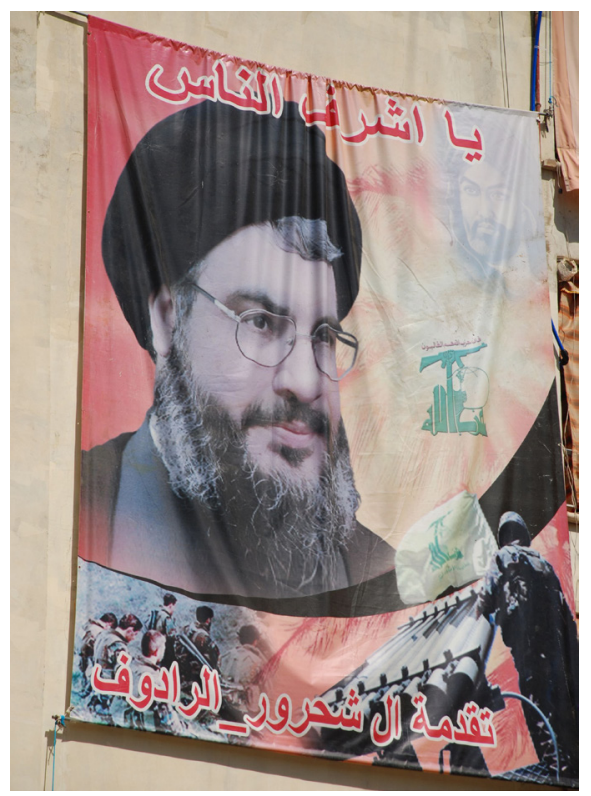

A Banner featuring Hezbollah leader Hassan Nasrallah

having suffered defeat at the hands of the Israelis in 1973, Syrian foreign policy became keener to the holistic strategy of Arab-Israeli conflict. In this calculated chess match, Syria began utilizing Hezbollah's resistance as an invaluable geographic and military weapon. Starting in the early 1980s, Syria pushed weaponry and money into the hands of the Hezbollah campaign, and thereby placed great pressure on Israel, and its controversial control over the Golan. ${ }^{5}$ At times over the past twenty years, Syrian influence has become so entwined with Hezbollah's political governance and military decision-making that some political commentators view Hezbollah simply as the radicalized alter ego of Syria, successfully offering leverage for Syrian interests. In the 1990s, Syria's strong military presence in southern Lebanon further complicated Hezbollah's political autonomy: "With 35,000 to 40,000 troops still in Lebanon, Syria was the real power broker in that country, and Hizbullah could not operate with impunity in Lebanon without Syrian assistance and acquiescence." ${ }^{\prime 6}$ However, although surrounding Arab nations have furnished startup capital and influenced Hezbollah during moments of warring regional interplay, Hezbollah's malleable political ideology has given the unique part-humanitarian/partterroristic organization the independence necessary to stand on its own two feet in the Middle East.

\section{The Evolution of Hezbollah Ideology}

The ideological foundation of Hezbollah arose from a conglomeration of Lebanese resistance efforts. The Israeli occupation, beginning in the 1980s, unified the divided Shiite population under several guiding principles.? In the nascent years of Hezbollah, militarism and jihadist demands underlay the burgeoning group. Lawrence Pintak depicts how the extremism sweeping Iran, northern Africa, and Palestine at that time also impacted Hezbollah's initial political ideology: "Among Hezbollah's demands- 'America, France, and their allies must leave Lebanon once and for all, and any imperial influence in the country must be terminated.' It sounded suspiciously like an Islamic Jihad communiqué. With good reason." ${ }^{8}$ The religious tinge connected to Hezbollah stood out in the Lebanese community, and became a polarizing factor as the group gained military and social clout. Hezbollah desired that southern Lebanon transition into an Islamic state, thereby coalescing into the broadening Iranian revolution. Although Hezbollah successfully grasped the loyalty of 
many hard-line Shiite clerics and politicians in the South, the group's founding platforms proved to be divisive within the whole of Lebanon, and Hezbollah was not able to cut across religious lines in the 1980s and early 1990s.

In 1992, Hasan Nasrallah ascended to the seat of Hezbollah secretary-general. As the spokesman for Hezbollah, Nasrallah has had the most pronounced role in moving the ideology of the group towards Clausewitz's political arm. As the relationship between Syria, Lebanon, and Israel grew tense in the early 1990s, Nasrallah reevaluated the assertive platforms of Hezbollah, and began to strategically shift the group's interests: "Nasrallah noted that 'We are serious in our project to bring down the government, but we shall not resort to negative steps... because the country is passing through a delicate stage."' ${ }^{\prime \prime 9}$ Although Nasrallah maintained a strong link between his military and political ideology, the charismatic leader drew in a larger bloc of believers because of his willingness to moderate goals and galvanize the masses with a novel sense of Lebanese nationalism. Thanks to Nasrallah, Hezbollah began "putting its 'Islamic state' on the back burner so it could operate more flexibly in a multi-communal society."10 Through the use of social works programs and secular grassroots political efforts, Hezbollah has been given the opportunity to gradually deemphasize its religious platforms. This has led to a surge in non-Shiite members to the Hezbollah camp. However, the greatest example of opportunistic ideological movement occurred in 2000:

On March 5, 2000, the Israeli cabinet pledged a withdrawal from Lebanon by July. The Israeli decision surprised and alarmed the Lebanese government and disconcerted its neighboring Arab states. Having established itself as a Shiite resistance movement against the Israeli presence in South Lebanon, Hezbollah's primary raison d'être would be removed. With Hezbollah's need for arms reduced, the role of its patrons Syria and Iran would also presumably be diminished. ${ }^{11}$
Hezbollah's leadership became existentially trapped: the group was forced to either amend its ideological aims once again or to accept military victory, therein burying any political future. By the late 1990s and early 2000s, Hezbollah had accrued the political, military, and economic support of many Lebanese constituents, and Nasrallah was not ready to sacrifice these political gifts for the sake of honestly confessing that Hezbollah had completed its original mission. So the political objectives of Hezbollah were redirected towards two foci. By promising to rebuild the entire Lebanese state, Hezbollah turned its efforts to

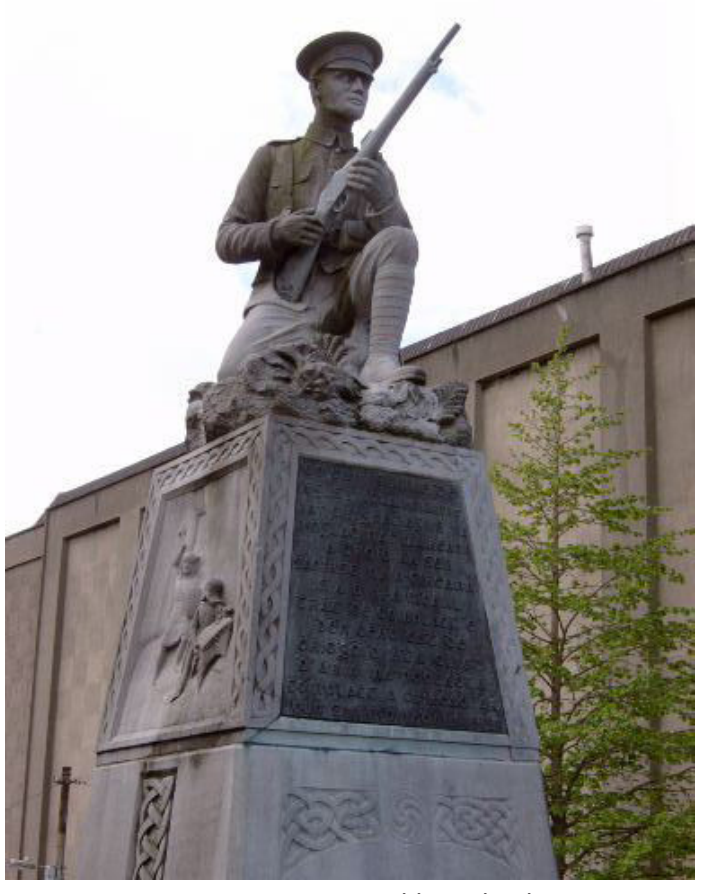

IRA Monument in Dublin, Ireland

the whole Lebanese people, not just southern Lebanese Muslims. Externally, years of anti-Israeli sentiment morphed Hezbollah's ideology into a trenchant support for the Palestinian cause; this "altruistic concern" allows Hezbollah to continue sporadic attacks against Israel, whenever the group believes that Palestinian interests are at risk. ${ }^{12}$ These ideological transformations, compounded by foreign influences, have shaped Hezbollah into a unique Middle Eastern group with a growing number of public supporters. 


\section{The Beginning of a Government Arm}

As aforementioned, Hasan Nasrallah revised the ideological trajectory of Hezbollah. However, his most important contribution to the group lies in his work to enter Hezbollah into Clausewitz's government arm. By channeling Hezbollah's popular support into the political sector, the group has been able to overcome some of the disadvantages attributable to nonstate entities. Although initially opposed to the creation of a political party, Hezbollah-under Nasrallah's leadership-eventually saw the benefits of joining the political ranks, and the Party of God became an official Lebanese political party in 1992.

Non-state actors are prone to eschew unity and compromise, instead attempting to chip away at the government bureaucracy and undermine the political process. After the end of the Israeli occupation, however, Hezbollah was given the opportunity to put its abstract ideology into political practice: "Immediately following the Israeli withdrawal from Lebanon... Hezbollah began systematically taking over Southern Lebanon and creating a state within a state. It worked towards deepening its control over the population by taking over the social and welfare arenas and managing the civilian services."13 Understanding that the current Lebanese government and military were too weak to confront the emergence of a provisional government, the Hezbollah leadership began to legitimize the political arm of Clausewitz's Trinity through the stimulation of a different branch of the Clauswitzian Trinity: the public arm.

Seeing the vacuum of social and financial support after 2000, the group amplified its social works programs-creating thousands of jobs, schools, houses, and medical operationsin order to rebuild the entire Lebanese state. These efforts, complemented by an enriched propaganda movement, merged the Lebanese people with the internal ideological promises of the Hezbollah party, and gave political standing to the group once known only for its terrorist activities. This reprioritization of politics over militarism gave Hezbollah political standing in the Middle Eastern community. Lawrence Pintak writes that these protective group efforts, designed to strengthen the Lebanese people, produced an element of international recognition: "Hezbollah, once just an elusive trend, was now negotiating treaties." ${ }^{14}$ By virtue of sitting down as a key actor in the Middle Eastern political process, Hezbollah acquired a de facto right to fight, and a legitimization for its anti-Israel political platforms. Most importantly, because Hezbollah has embraced the role of military, social, and governmental protector of the Lebanese people, this political party has become inextricably linked to the political stability of the nation: "As long as Hezbollah was part of the system, we knew there was a good chance for stability to take hold," said one American diplomat familiar with Lebanon, "but if something drove them out of the process, all bets were off."15

Although the United States has funneled hundreds of millions of dollars, and great quantities of military equipment, into Lebanon to protect the political integrity of the

Through the use of social
works programs and secular
grassroots political efforts,
Hezbollah has been given
the opportunity to gradually
deemphasize its religious
platforms

Lebanese government, Hezbollah continues to use its political power to safeguard its military operations, and to vitiate the work of Lebanon's official government. ${ }^{16}$ Following the 2006 conflict with Israel, Hezbollah was pressured by the international community to disarm; because the original political objectives of the organization had been achieved in 2000, multiple nationsalong with the United Nations-believed that Hezbollah no longer possessed a need for stockpiled arms, especially if the group was completely dedicated to the political arena. ${ }^{17}$ Hezbollah resisted these persistent entreaties and 
became more volatile to the Lebanese, Israeli, and American governments. In this way, Hezbollah has not separated its military activities from its political leadership, but has allowed instead for a terrorist/political/social works amalgamation to continue. Because of this diverse organizational complexion, the same foreign counsel that oversees Hezbollah's political activities still oversees its economic, military, and social efforts.

\section{Hezbollah and the IRA: Beginning Comparative Analysis and Shared Characteristics}

Hezbollah has achieved a successful entrance into the Lebanese political arena, and in so doing has garnered a degree of international recognition and a current bloc of popular support. However, a succinct overview of the Northern Irish republican movement's transition into government shows that a non-state entity's sociopolitical gains will only sustainably exist through a developed political branch of the

\section{The Irish Republican Army of the late twentieth century arose out of grave social, economic, and political inequalities}

Clausewitzian Trinity. The Irish Republican Army (IRA) provides a reasonable case for comparative analysis with Hezbollah; the juxtaposition of these two groups is made possible by the fact that despite being politically, geographically, religiously, and culturally dissimilar, the IRA and Hezbollah display multiple shared characteristics.

Ideologically, both the IRA and Hezbollah allow religion to become tied to their respective resistance movements. Whereas Hezbollah maintains strong links to the Islamic faith, the Northern Irish "Troubles" pit an overwhelmingly Irish Catholic republican base against the proBritish Protestant population. Additionally, the ideological context buoying up the two militant movements was created by the presence of an occupying force and by the imposition of a disagreeably foreign way of life. For the southern Lebanese, Israel represented this occupying force; for the Northern Irish Catholic population, the British government and its privileged Protestant populace threatened Irish unity and led to unequal political and economic conditions.

In the political arena, the IRA and Hezbollah also share many commonalities. Like the Syrian and Iranian-backed Hezbollah group, the IRA has always attempted to expand its foreign relations, often benefiting from financial backers and arms suppliers in the Western world (which has included millions of dollars of support from American citizens). Most strikingly, the cardinal political demands of the Irish Republican Army parallel those of Hezbollah: the IRA demands the withdrawal of all British forces and the termination of all political intrusion into Northern Irish governance, as well as greater political autonomy and stronger ties with Ireland (which is geographically-linked to Northern Ireland). Additionally, just as many Lebanese view Hezbollah as the people's protectors, the Irish republican movement has spent the past five decades fighting for the political and social equality of the Northern Irish Catholic population. However, although these important similarities exist, which make comparison between the two militant organizations possible, the Irish republican movement's political success presents a more successful Clausewitzian model.

\section{The Troubles}

The Irish Republican Army of the late twentieth century arose out of grave social, economic, and political inequalities in British-controlled Northern Ireland. In the late 1960s, non-violent political activists began campaigning in Northern Ireland against the "second-class status of Catholics with regards to voting rights, job opportunities, and housing"; sadly, this predominantly-Catholic movement was met with violent animosity by Protestant business owners and political heads. ${ }^{18}$ Political commentator Deaglan de Breadun writes, "The political system in Northern Ireland, dominated by an inflexible unionist elite, was unable to accommodate the demands of the Catholics and integrate them into a pluralistic, inclusive society 
with opportunity for all. The fact is that Northern Ireland was set up to maintain Protestant supremacy."19 By the early 1970s, the Troubles had officially begun; the Troubles denote a period in Northern Ireland history that saw the rise of a largely Catholic paramilitary force-the IRA-confronting British soldiers and pro-British Protestant forces with the aim of removing British influence from the land, and providing equality to the Catholic population. However, as the movement progressed into the 1990s, although billions of dollars of British military, intelligence, and business assets had been drained, not to mention the loss of thousands of pro-British Unionist lives, the Irish Republican Army found itself in a similar quandary to what Hezbollah faces today: the realization that military means alone cannot overcome enemy resources, although the organization's ideological foundations and popular support call for continued resistance.

\section{Reshaping the Arms of the Irish Republican Movement}

It was during this predicament that Sinn Fein leader Gerry Adams helped to redirect the Irish republican movement. It was the work of Adams, and more broadly, the work of Sinn Fein, which helped Irish republicanism access lasting victories in the political branch of Clausewitz's Trinitarian model. As the growing political arm of the Northern Irish republican movement, Sinn Fein held political objectives that had traditionally aligned with the sociopolitical goals of the Irish Republican Army. The first landmark step that Sinn Fein took in reshaping the Irish republican movement was to move away from the Armalite and ballot box strategy, thus separating the military leadership of the republican movement from Sinn Fein's political leadership. By distancing the political arm from the movement's more militaristic arm, Sinn Fein tacitly acknowledged that "the IRA's activities were often counterproductive and hindered the growth of the republican movement's political influence."20 The separation given between the military and political arms led to numerous strategic benefits for the Irish republican movement. The distancing act empowered the republican government arm and opened the movement up to a broader popular base. The delicate balance between the arms of the Clausewitzian Trinity improved as the public sphere became more receptive to the republicans' shift to honest politics: "While Sinn Fein continues to press to make partition history, the more immediate and tangible gains of the agenda make the party's revisionist republicanism attractive to the nationalistic electorate for which armed struggle and militant paths to unity were always a minority taste." 21

Whereas the Irish republicans had generally utilized the political arena in the service of military objectives, Sinn Fein reversed this paradigm. The military's presence was to be gradually tuned out, and in the rare instances when the military arm of the resistance was required, it became an instrument of republican political interests:

For the IRA, coercive bargaining will normally involve indicating to the adversary, through military action, that the costs of not acceding to its political demands will outweigh the costs of concession. In this sort of conflict the weaker party may not be able to achieve any tangible military objectives, such as securing a piece of territory. Instead, as Clausewitz observed, another military objective must be adopted that will serve the political purpose and symbolize it in peace negotiations. ${ }^{22}$

Another important component
of the military phase-out and political empowerment occurred when Sinn Fein sat down for international peace talks. As Sinn Fein strengthened its public and governmental resolve in the 1990s, the political party eventually began to negotiate a lasting peace treaty with the British, Irish, and Northern Irish governments. In order to access sustainable economic, political, and social gains for the Catholic community, the republican movement would have to concede considerable ground. Firstly, the Irish republicans 
had to actively renounce the use of terrorism, and gradually disarm their military wing. Secondly, the hard-line ideological goals set up during the 1970s had to be supplanted by limited gains within the state. And as Gerry Adams pointed out, these gains would only actualize through political compromise and strategic coalition: " Irish republicans... simply do not possess the political strength to bring about these aims. [This truth] must continue to influence the political and strategic thinking of Irish republicans.' The focus of republican politics, according to Adams, should be on'attempting to reconstruct a broader, deeper, sustainable Irish political consensus."'23 By the end of the 1990s, the Irish republicans' ability to politically adapt, compromise, and demilitarize led to the greatest advancement of Catholic legal and social equality in modern Northern Irish history: the Good Friday Agreements of 1998.

Ideologically, Sinn Fein discovered a path to sociopolitical success by embracing principles of moderation, humility, and secularism. The religious impetus of the resistance movement, which unified the Catholic population under the IRA banner, was supplanted in the 1990s by secular political backing. Colin Coulter and Michael Murray assert, "The Catholic Church is now much less politicized than at the height of the Troubles when priests joined civil rights protests and visited hunger strikers. The politics of peace have meant that the Catholic Church is increasingly taking a political back seat... [especially] since the decline in violent conflict."24 The revised role of international influence also portrayed the humility, and militaristic moderation, of the 1990s Irish republican movement. Historically, the Irish republicans had turned to American citizens and other developed Western nations solely for financial backing and arms dealing. In the 1990s, however, Sinn Fein helped coordinate the Mitchell Review, which provided necessary multinational oversight to move the peace process along and to hold each party accountable for disarmament and political compromise. ${ }^{25}$ By turning to the international community for aid in humanitarian and political processes, the Irish republicans finally achieved their sociopolitical aims and gained lasting political legitimacy around the world.

\section{Conclusion}

The Irish republican movement's gradual evolution into a purely political existence offers many significant lessons to the modern Hezbollah campaign. In 2006, Hezbollah's rejection of international calls for disarmament highlighted the group's inability to successfully balancing the political and military arms of Clausewitz's Trinity model. As Hezbollah demonstrated its weak dedication to the political arena, the United States, Israel, and numerous other developed nations became emboldened in their aggression against the southern Lebanese group. In order for Hezbollah to sustainably access its sociopolitical goals, it must be willing to adjust its outlook in the political wing of Clausewitz's Trinity model.

The Irish republican movement proved to non-state actors that the government arm of an organization must become distanced from the organization's military arm. Along with this distancing, political leaders must be willing to separate themselves from military leadership if they ever hope to strengthen the popular wing of the Trinity model. In order to make headway in the path to sociopolitical success, the Irish republican movement confirmed the need for arms reductions and became willing to enter into the peace process. By developing into a secular political entity capable of compromise with other parties, non-state entities gain international legitimacy and social acceptance from local governments. In order for Hezbollah to see their ideological teloi come into fruition, they must be willing to moderate their political expectations, embrace international oversight, and decrease military presence within the organization. If the non-state Shiite entity is capable of making these significant revisions, every wing of the Clausewitzian Trinity will be strengthened and the Lebanese population may one day discover lasting political peace and social improvement. 


\section{Endnotes}

1 Carl von Clausewitz, On War (London: N. Trubner, 1873), 89.

2 Ibid. 89.

3 Sandra Mackey, Lebanon: Death of a Nation (New York: Congdon \& Weed, 1989), 206.

4 Augustus Richard Norton, Amal and the Shi'a: Struggle for the Soul of Lebanon (Austin: University of Texas Press), 102. 5 Ian J. Bickerton and Carla L. Klausner, A History of the Arab Israeli Conflict (Upper Saddle River: Prentice Hall, 2010), 312.

6 Ibid. 279.

7 Lawrence Pintak, Seeds of Hate (Sterling, Virginia: Pluto Press, 2003), 290.

8 Ibid. 228.

9 William Harris, Faces of Lebanon (Princeton: Markus Wiener Publishers, 1997), 302.

10 lbid. 302.

11 Ian J. Bickerton and Carla L. Klausner, A History of the Arab Israeli Conflict (Upper Saddle River: Prentice Hall, 2010), 318.

12 Lawrence Pintak, Seeds of Hate (Sterling, Virginia: Pluto Press, 2003), 314.

13 Committee on International Relations, Hezbollah's Global Reach (Washington DC: U.S. Government Printing Office, 2006), 39.

14 Lawrence Pintak, Seeds of Hate (Sterling, Virginia: Pluto Press, 2003), 292.

15 Ibid. 318.

16 Committee on Foreign Affairs, The Political Situation in Lebanon (Washington DC: U.S. Government Printing Office, 2007), 4.

17 lbid. 11.

18 Deaglan de Breadun, The Far Side of Revenge: Making Peace in Northern Ireland (West Link Park: The Collins Press, 2008), 2.

19 lbid. 2.

20 lbid. 4.

21 Colin Coulter and Michael Murray, Northern Ireland after the Troubles (Manchester: Manchester University Press, 2008), 57.

22 M.L.R. Smith, Fighting for Ireland? The Military Strategy of the Irish Republican Movement (London: Routledge 1995), 3.

23 Ibid. 198.

24 Colin Coulter and Michael Murray, Northern Ireland after the Troubles (Manchester: Manchester University Press, 2008), 143.

25 Christopher Farrington, Global Change, Civil Society, and the Northern Ireland Peace Process (New York: Palgrave MacMillan, 2008), 10.

Photo credits: Wikimedia Commons 